\title{
Malachi's use of תִּרָ in dialogue with the Wisdom Tradition of Proverbs ${ }^{1}$
}

\author{
BLESSING ONORIODE BOLOJE (UP)
}

\begin{abstract}
This article examines Malachi's use of תרוֹ in dialogue with the wisdom tradition of Proverbs. The proposition of the article is that wisdom in the book of Proverbs is tôrāh-oriented and that Malachi's use of tôrāh serves to present and elevate tôrāh as Israel's Wisdom Tradition/teaching. The ideas of hearing, keeping, or forsaking the tôrāh in Prov 28:4, 7, 9; 29:18 correspond to the idea of remembering the tôrāh of Moses in Mal 3:21. Within the contextual perspective of the Mosaic covenant, it is believed that keeping the Mosaic tôrāh constitute wisdom for Israel (Deut 4:6; cf. Ps. 19:7; 119:130). As taught in the OT, wisdom is, in some extent, the manifest expression and outworking of the Yahweh's law in the heart and life. Thus, in light of the close connection between tôrāh and wisdom in the OT, this article presents a general understanding of wisdom relative to the $H B$ as a background, it examines tôrāh wisdom from selected passages in the book of Proverbs, analyses the use of tôrāh in Malachi's dialogue and then concludes with a synthesis of the relationship between tôrāh wisdom in Proverbs and tôrāh usage in Malachi's dialogue.
\end{abstract}

KEYWORDS: tôrāh-wisdom; Proverbs; Malachi; wisdom tradition; remembering and forsaking tôrāh; Mosaic Covenant.

\section{A INTRODUCTION}

In the Hebrew Bible/Old Testament (HB/OT), the noun, (tôrāh, "law"), is regarded as a foundational theological concept as it embraces and represents a number of different connotations and understanding in diverse ancient Israelite societal and communal backgrounds. Jonathan Ben-Dov writes:

The term tôrāh is a keystone of biblical religion, and as such it embodied several divergent meanings in various social settings of

* Submitted: 20/10/2017; peer-reviewed: 03/12/2017; accepted: 01/03/2018. Blessing Onoriode Boloje, "Malachi's Use of תוֹרָ in Dialogue with the Wisdom Tradition of Proverbs," OTE 31 no. 1 (2018): 243-263. DOI: https://doi.org/10.17159/2312$\underline{3621 / 2018 / \mathrm{v} 31 \mathrm{n} 1 \mathrm{a} 12}$

$\frac{362}{1}$ This article is a revised version of the paper presented at the Old Testament Society of South Africa (OTSSA) held at the University of Pretoria, South Africa, September 6-8, 2017. 
ancient Israel. In the Wisdom literature it denoted the meaning of a general, usually secular instruction, which never takes written form. On the other hand, in priestly literature the word tôrāh denotes a short instruction which relates to the ritual realm-sacrifices, purity, leprosy, etc. This kind of instruction, always supplied by priests, was committed to writing in a series of short scrolls, and is presently collected into one priestly continuum in the Pentateuch. ${ }^{2}$

The noun means basically instruction or teaching ${ }^{3}$ and fundamentally, a pointing out, a direction or authoritative direction from Yahweh. It gives the God-ordained direction to life such that a lawless life is a directionless life. ${ }^{4}$ The Bible does not recognise any law as valid apart from the law of God, given by a revelation to the patriarchs and Moses, ${ }^{5}$ and expounded by the prophets. Israel's very existence and relationship to God necessitated a law (tôrāh) or authoritative direction.

2 Jonathan Ben-Dov, "Some Precedents for the Religion of the Book: Josiah's Book and Ancient Revelatory Literature," in Constructs of Prophecy in the Former and Latter Prophets and other Texts, ed. Lester L. Grabbe and Martti Nissinen, ANEM 4 (Atlanta: Society of Biblical Literature, 2011), 50.

3 In his essay on the meaning of Torah, Roland Clements notes that the noun has become identified with a specific body of tradition which has been preserved in the written document and subsequently extended to include all the Five Books of Moses and not just the broad and occasional instruction. See Roland E. Clements "The Meaning of Torah in Isaiah 1-39" in Reading the Law: Studies in Honour of Gordon J. Wenham, ed., J. Gordon McConville and Karen Miller, LHBOTS 461 (New York: T \& T Clark International, 2007), 62. See also Barnabas Lindars, "Torah in Deuteronomy," in Words and Meanings: Essays Presented to David Winton Thomas, ed. Peter R. Ackroyd and Barnabas Lindars (Cambridge: Cambridge University Press, 1968), 12832; E. Ray Clendenen, "Malachi," in Haggai, Malachi, ed. Richard A. Taylor and E. Ray Clendenen; NAC 21A (Nashville: Broadman and Holman Publishers, 2004), 457; Alphonso Groenewald, "The Significance of הרות (Isa 2:3) within Isaiah 2:1-5: The Relationship of the First Overture (1:1-2:5) to the Book's Conclusion (Isa 65-66)," OTE 26/3 (2013): 697. Alphonso Groenewald, "The Role and Function of Sedaqa and Torah in the Introduction to the Book of Isaiah (1.1-2.5)," in Sedaqa and Torah in Postexilic Discourse, ed. Suzanne Gillmayr-Bucher and Maria Häusl, LHBOTS 640 (New York: T\&T Clark, 2017), 71-85.

4 Rousas John Rushdoony, The Institutes of Biblical Law (Nutley, NJ: The Craig Press, 1973), 689.

5 The tôrāh of Moses (cf. Josh $1: 7-8 ; 8: 34 ; 22: 5 ; 23: 6$ ) is mostly a Deuteronomic concept. Pekka Pitkanen, "The Use of Priestly Legal Tradition in Joshua and the Composition of the Pentateuch and Joshua," OTE 29/2 (2016): 322. For the concept of the tôrāh of Moses see, Emanuel Tov, Textual Criticism of the Hebrew Bible, 3rd ed. (Minneapolis: Fortress Press, 2012), 294-299. 
On the other hand, the Hebrew word for "wisdom" is the feminine noun

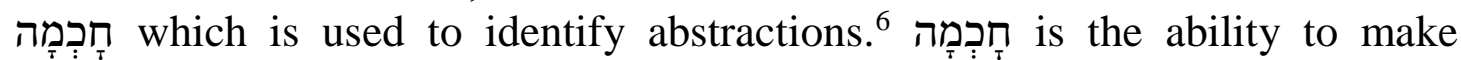
informed decisions and judgements based on personal knowledge and experience at every opportune moment. ${ }^{7}$ The consistency in making such informed decisions is an indication of maturity and development. In the OT, the category of wisdom is wide-ranging. It embraces insight and understanding, intelligence and discernment (see Prov 5:1; 10:13) and also technical and artistic ability with a practical outlook. "It is the possession of whatever abilities were necessary for a practical individual to be successful in their own sphere of life." 8 The foundational prerequisite for attaining wisdom is the fear of the LORD (Prov 1:7; 9:10). ${ }^{9}$ Essentially, the worldview of wisdom begins with people. Wisdom teachings probably began in the family or clan: ${ }^{10}$ parents, elders and other wise teachers had learned from their experiences of the world and had words of wisdom to pass on to each succeeding generation, in addition to instruction about family responsibilities, the value of hard work and the folly of laziness. ${ }^{11}$ The underlying assumption is that human beings learn from experience and that such experience can be communicated in the writings of the Wisdom literature. ${ }^{12}$

For ancient Israel, wisdom is essentially an approach to life, a means of embodying their commitment to God in a very deliberate and intelligent manner. Within the contextual perspective of the Mosaic covenant, it is believed that keeping the Mosaic tôrāh constitute wisdom for Israel (Deut 4:6; cf. Ps 19:7; 119:130). As taught in the OT, wisdom is, to some extent, the manifest expression and effect of Yahweh's law in the heart and life. Thus, in light of the close connection between tôrāh and wisdom in the OT, this article seeks to develop the proposition that wisdom in the OT and relatively in the book of Proverbs is tôrāh-oriented and that Malachi's use of tôrāh in his dialogues serves to present and elevate tôrāh as Israel's Wisdom teaching. In the following sessions, the article presents a general understanding of wisdom relative to the $\mathrm{HB} / \mathrm{OT}$ as a background, it examines tôrāh wisdom from selected passages in

6 Richard S. Hess, The Old Testament: A Historical, Theological and Critical Introduction (Grand Rapids: Baker Academic, 2016), 461.

7 Nathaniel A. E-Agbikimi, Wisdom: A Prerequisite for Long Life in a World Full of Hazards (Effurun: Journey Designs, 2011), 27.

8 John Drane, Introducing the Old Testament, 2nd rev. ed. (Minneapolis: Fortress Press, 2001), 280.

9 E-Agbikimi, Wisdom, 31.

10 Roland Clements has strongly emphasized the importance of the household, both as a context for teaching and learning and as a subject for instruction. Roland E. Clements, Wisdom Theology (Carlisle: Paternoster, 1992), 126-150.

11 Robin Routledge, Old Testament Theology: A Thematic Approach (England: InterVarsity Press, 2008), 217.

12 James L. Crenshaw, Old Testament Wisdom: An Introduction, 3rd ed. (Louisville: Westminster John Knox, 2010), 11. 
the book of Proverbs, analyses the use of tôrāh in Malachi's dialogue and then concludes with a synthesis of the relationship between tôrāh wisdom in Proverbs and tôrāh usage in Malachi's dialogue.

\section{B OVERVIEW OF WISDOM IN THE HEBREW BIBLE/OLD TESTAMENT}

The ancient world developed writings in a mixture of literary categories with the earliest Wisdom literature dating from around $2000 \mathrm{BCE} .^{13}$ The general concern that inspired and motivated the development and writing of Wisdom literature includes: first, the exploration of philosophical issues and ideas (Job and Ecclesiastes belong to this category). In Job, one encounters the debate about the suffering of the righteous, and in Ecclesiastes there is the contemplation on the critical question of the meaningfulness of life. A follow-up to this motivation of the authors of the Wisdom literature, is the concern that they provide a viable platform for counselling and giving of advice on how to live a practical, rational and level-headed life. This is the category to which Proverbs belongs, with all its precise and sharp counsels and sayings on the practical and moral decisions that individuals take in life. ${ }^{14}$

A number of modern researchers have questioned the perception of Wisdom literature as a unique literary genre and wisdom tradition as a literary development in the HB/OT. ${ }^{15}$ In his essay, Mark R. Sneed maintains that no satisfactory reconstruction can be made in order to define wisdom tradition whether generic realism or generic nominalism. According to him, Wisdom literature or tradition should be seen as a "mode of literature." 16 Will Kynes advances that the term wisdom tradition should not be used in biblical scholarship. His essay provides a comparative explanation of certain tendencies namely; "pan-Sapientialism" and "pan-Deuteronomism" which he considers as poorly defined wisdom categories. ${ }^{17} \mathrm{He}$ thus offers a proposal for clarifying

13 The Wisdom literature of the OT consists of the books of Job, Proverbs Ecclesiastes and some Psalms $(19,37,104,107,147,148)$. This does not mean that other books of the Bible do not contain wisdom, but the aforementioned books are categorised as books of wisdom for they contain more words of wisdom than other forms of literary writings. Lawrence O. Richards, Bible Reader's Companion (Eastbourne, England: Cook Communications Ministries, 2004), 382.

14 Richards, Bible Reader's, 382.

15 See the various collections of essays in Mark R. Sneed, ed., Was There a Wisdom Tradition? New Prospects in Israelite Wisdom Studies, AIL 23 (Atlanta: SBL Press, 2015).

16 Mark R. Sneed, "'Grasping after the Wind': The Elusive Attempt to Define and Delimit Wisdom," in Was there a Wisdom Tradition? New Prospects in Israelite Wisdom Studies, ed. Mark R. Sneed, AIL 23 (Atlanta: SBL Press, 2015), 41.

17 Will Kynes, "The Modern Scholarly Wisdom Tradition and the Threat of PanSapientialism: A Case Report," in Was there a Wisdom Tradition? New Prospects in 
similarities, "the formalization of intertextual comparisons made by a group of readers." 18 In his essay, Douglas Miller notes that Wisdom literature has a unique posture and voice from other literary works of the HB/OT and that the term wisdom persists as a literary category. He describes seven general features of Wisdom literature that stressed essential components of the wisdom corpus namely; "form," "social location," "technical vocabulary," "humanistic orientation," "didacticism," "eudemonism," and "Weltanschauung." $\mathrm{He}$ however reduces these central indicators heuristically to three basic and essential pointers namely; "persuasive rhetoric" (that is, instruction), "realized eschatology" (focus on present mundane existence), and "experiential epistemology" (grounded in human experience). ${ }^{19}$

In his essay, Michael V. Fox notes that what makes wisdom unique from other literary categories in the HB/OT is not really about conventional subjects but "stylistic and theological differences" and that these unique differences are "features of the genre's goals, not of the authors' mentality." ${ }^{20}$ Although he observes the need to reformulate a new nomenclature for the wisdom genre, he believes the Wisdom literature as embodiments of insights for ethical living. ${ }^{21}$ In "Deciding the Boundaries of Wisdom: Applying the Concept of Family Resemblance," Katharine J. Dell while steering clear of the use of wisdom tradition affirms the abiding significance of the category of wisdom in the HB/OT. She proposes three basic principles for redefinition of the frontiers of Wisdom literature namely "ruling wisdom thrust," "intellectual tone," and "didactic speech intention." She presumes that the category of genre is still very relevant on the condition of well-informed definition and that the language of form, content, and contexts still thrive. She applies her "Concept of Family Resemblance" to the relationship that exists between the books of Proverbs and Ecclesiastes and this helps one to consider them as "the core of wisdom."22

Israelite Wisdom Studies, ed. Mark R. Sneed, AIL 23 (Atlanta: SBL Press, 2015), 2023.

18 Kynes, "Modern Scholarly," 32.

19 Douglas Miller, "Wisdom in the Canon: Discerning the Early Intuition," in Was there a Wisdom Tradition? New Prospects in Israelite Wisdom Studies, ed. Mark R. Sneed, AIL 23 (Atlanta: SBL Press, 2015), 87-114.

20 Michael V. Fox, "Three Theses on Wisdom," in Was there a Wisdom Tradition? New Prospects in Israelite Wisdom Studies, ed. Mark R. Sneed, AIL 23 (Atlanta: SBL Press, 2015), 74.

21 Fox, "Three Theses," 80.

22 Katharine J. Dell, "Deciding the Boundaries of Wisdom: Applying the Concept of Family Resemblance," in Was there a Wisdom Tradition? New Prospects in Israelite Wisdom Studies, ed. Mark R. Sneed, AIL 23 (Atlanta: SBL Press, 2015), 156. 
Whilst wisdom teaching was prominent throughout the ANE, ${ }^{23}$ wisdom in the OT has a clear theological focus; wisdom without God is lacking, and the wisest plans, made without reference to God, will be confounded (for example, Isa 10:13-16; 19:12-13). ${ }^{24}$ "True wisdom is possessed by and proceeds from God, and may only be properly discovered by those who know God." 25 The growth of wisdom movement in ancient Israel is closely related to the monarchy with a link to Solomon. ${ }^{26}$ In the HB, wisdom employs traditional forms, such as proverbs, and disputation, but with some degree of transformation by its integrative worldview and its potential to challenge and accommodate acceptable explanations and interpretations of both human and divine experiences. ${ }^{27}$ Lawrence O. Richards notes:

All the chief literary forms used in the Wisdom literature are reflected in the Old Testament Wisdom books of Proverbs, Job, Ecclesiastes, and in many of the wisdom psalms. These are: the sentence saying, or proverbs; the short precept followed by a discussion; the rhetorical question; soliloquy; debate; descriptive or contemplative poetry; imaginative tales; and illustrative anecdotes. ${ }^{28}$

The use of these forms does not occasion any conflict between the prophet's call to the requirements of righteousness and justice and the sage's encouragement to be wise. Wisdom and righteousness go together; for the one who is honestly wise and who is conscious of the presence of Yahweh will choose to do the requirements of Yahweh's tôrāh. ${ }^{29}$ The one who truly fears Yahweh, in the manner of upholding his tôrāh, will make prudent decisions and can expect to live a secure and happy life. This primary reflection on Yahweh and of wisdom as a faith and tôrāh-rooted righteousness establishes HB/OT

23 Egypt and Mesopotamia are among Israel's religious neighbours where speculative reflections and discursions of some of life's difficult issues, such as meaning of life or the problem of the suffering that one finds in the OT are located. Roland Murphy, "Wisdom," ABD 6: 928; Derek Kidner, The Wisdom of Proverbs, Job and Ecclesiastes (Downers Grove: Inter-Varsity Press, 1985), 125-141; Bill T. Arnold and Bryan E. Beyer, Readings from the Ancient Near East: Primary Sources for Old Testament Studies (Grand Rapids: Baker, 2002), 175-179.

24 Routledge, Old Testament Theology, 216.

25 Routledge, Old Testament Theology, 220.

26 Rainer Albertz, From the Exile to the Maccabees, vol. 2 of A History of Israelite Religion in the Old Testament Period (Louisville: Westminster John Knox Press, 1994), 512.

27 Bruce K. Waltke and David Diewert, "Wisdom Literature," in David W. Baker and Bill T. Arnold, eds., The Face of Old Testament Studies: A Survey of Contemporary Approaches (Grand Rapids: Baker, 1999), 301.

28 Richards, Bible Reader's, 384.

29 Richards, Bible Reader's, 384. 
wisdom/Wisdom literature as unique. ${ }^{30}$ Since God in the OT is a living and vital personality, he directed the aftermaths of human moral actions, punishing evil and rewarding good. In this regard, the hard wisdom conveyed in proverbial advices and sayings in the HB/OT had a unique urgency. ${ }^{31}$

\section{C tôrāh WISDOM IN PROVERBS}

The book of Proverbs is believed to have originated as a composition of wisdom schools and of the royal court and of its training of scribes and princes on the one hand and on the other hand the wisdom sayings began in the oral context of village life and of the tribes, where early Israel began. ${ }^{32}$ Whilst a professional band of wisdom teachers during the Israelite monarchy may be responsible for the production of wisdom sayings, it is obvious in the book of Proverbs that several verses link the wisdom sayings with kings, especially Solomon and Hezekiah (Prov 1:1; 101; 25:1; cf. 1 Kgs 3:5-9; 4:32). ${ }^{33}$ In early and medieval Christian literature, Proverbs was considered to be the introduction to the corpus of Wisdom literature as found in the Bible and the "deuterocanonical literature" and in the second millennium of Christianity; it became a book treasured for its practical wisdom more than for any theological issues that might have divided Jews and Christians. ${ }^{34}$

The book is made up of two distinct parts: chapters 1-9 and 10-31. The first part of nine (9) chapters contains wisdom discussions. This section pictures "the 'mega image' of the book, encountering countering Women Wisdom on the part of life," 35 and her alternative rival, Madam Folly. ${ }^{36}$ The second section contains two-line pithy statements which are mainly Proverbs. It characterises the book's title among its contemporary readers and interpreters. Daniel P. Bricker stresses that

A key to understanding the wisdom in the book of Proverbs is to understand the "two ways" concept used to teach the importance of

\footnotetext{
30 Richards, Bible Reader's, 385.

31 Richards, Bible Reader's, 384.

32 Hess, Old Testament, 459.

33 Hess, Old Testament, 459.

34 Hess, Old Testament, 457.

35 Tremper Longman III, How to Read Proverbs (Downers Grove: Inter-Varsity Press, 2002), 42. A number of critical scholars regard these chapters as originating from the exilic and postexilic periods with Solomon having little or nothing to contribute to the composition. Steinmann had however written to defend Solomonic authorship of 1-9 in Andrew E. Steinmann, "Proverbs 1-9 as a Solomonic Composition," JETS 43/4 (2000): 660-74.

36 Hess, Old Testament, 464.
} 
choosing wisely which path or lifestyle would be followed: the path of the wise and righteous, or the way of the foolish and wicked. ${ }^{37}$

The author identifies the purpose of the book as a matter of acquiring

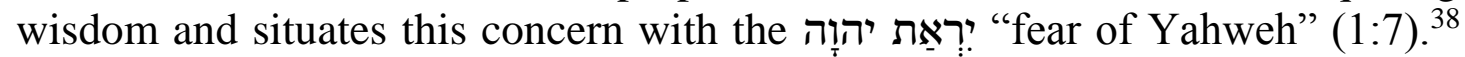
The syntagmatic concept ירָאָת יהוֹ "fear of Yahweh” is generally recognised and accepted as both the credo and theological and epistemological bedrock of the book. ${ }^{39}$ It is a concept that generally connotes reverential surrender to Yahweh's will that epitomises Yahweh's true worshippers and not of trembling fear that weakens action, neither is it of polite reverence. ${ }^{40}$ The wisdom in the book of Proverbs has to do with morality, especially the knowledge that is required to live a life of impact, the beginning point being the fear of God. The book tries to show the basic rules of good behaviour that is integrity, discipline, justice and common sense. It also reveals the failure that awaits the fool. ${ }^{41}$ According to the Proverbs, the way to live successfully is governed by rules of right and wrong. ${ }^{42}$

While there is an obvious lack of preoccupation with tôrāh in Proverbs, the book of Proverbs is essentially about tôrāh as the direction and guide of life. The tôrāh in Proverbs, where it appears unqualified $(28: 9 ; 29: 18)$ clearly refers

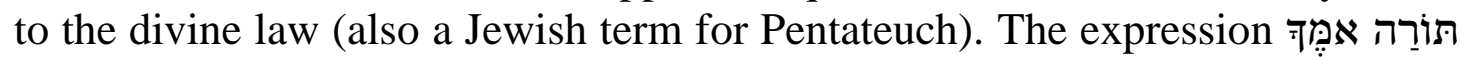
("your mother's tôrāh," Prov 1:8), among others refers to home teachings with focus on the tôrāh but not necessarily equal to it. ${ }^{43}$ In this regard,

all direction rests and must rest on Yahweh's fundamental tôrāh, law or direction. A parent's law, a teacher's or employer's law must be the right application of Yahweh's tôrāh. ${ }^{44}$

Thus when Yahweh's tôrāh is properly applied it becomes the fundamental principle and fabric of life and direction of human society. ${ }^{45}$ In keeping with this understanding, the following texts are examined:

37 Daniel P. Bricker, "The Doctrine of the 'Two Ways' in Proverbs," JETS 38/4 (1995): 500.

38 Hess, Old Testament, 461.

39 Bruce K. Waltke, The Book of Proverbs, Chapters 1-15, NICOT (Grand Rapids: Eerdmans, 2004), 180.

40 Allen P. Ross, "Proverbs," in The Expositor's Bible Commentary, 12 vols., ed. Frank E. Gaebelein (Grand Rapids: Zondervan, 1991), 5:907.

41 Israel Kristilere, Seven Pillars of Wisdom (Lagos: Oasis of Faith Ventures, 2014), 18.

42 Kristilere, Seven Pillars, 19.

43 Derek Kidner, Proverbs: An Introduction and Commentary (Downers Grove: InterVarsity Press, 1975), 63.

44 Rushdoony, Institutes, 690

45 Rushdoony, Institutes, 690. 
He who scorns instruction will pay for it, but he who respects a command is rewarded. The tôrāh (teaching) of the wise is a fountain of life, turning a man from the snares of death (Prov 13:13-14).

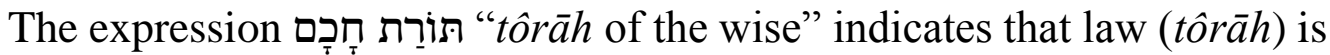
used here in its original sense of "direction" or "instruction." 46 It is the actual voice of spiritual experience rather than divine command, though it will be in compliance with the Tôrāh. ${ }^{47}$ Yahweh's tôrāh is given to all mankind; the godly society and godly men will mediate that tôrāh to each new generation and will thus ensure their health and welfare. This is why Franz Delitzsch remarked:

The proverb is designed to state that the life which springs from the doctrine of the wise man, as from the fountain of health, for the disciple who will receive it, communicates to him knowledge and strength, to know where the snares of destruction lie, and to hasten with vigorous steps away when they threaten to entangle him. ${ }^{48}$

Yahweh's tôrāh must be the standard of right and wrong for moral and responsible creatures and this must be appreciated in proportion to its perfection. It is a necessity to educate humanity's moral sense (13:13a) and is required as a basis of punishment and reward (13:13b). The wise man lives according to tôrāh - תוֹרֵת חָכָם "the law of the wise." Where men live without a rule of life, there is power without law, and this must work evil and not good. It is the characteristic of a morally wise man that all his powers of mind and soul are under control. Living by rule gives distinctness and definiteness to life, and thus augments its power. A lawless man possesses a terrible capacity for destruction; but his power reduces as he exercises it, while he is under Divine rule grows stronger and stronger. Snares are laid to turn men's power into wrong channels so as to bring their lives under the dominion of lawlessness - "snares of death." It is a snare of death because power without rule destroys itself and others; but the snare is avoided by close adherence to Yahweh's tôrāh.

As a rule by which the morally wise are governed, Yahweh's tôrāh is first abundant: "it is a fountain" which originates in God and thus an all-sufficient guide or rule of life for men in all ages and under all circumstances. Second, it is life-giving (fountain of life) such that when allowed to flow through the garden of the soul, and exert there its due influence, produces fruit unto holiness and the end everlasting life. Psalm 19:7-11 validates this testimony:

${ }^{7}$ The law of the LORD is perfect, reviving the soul. The statutes of the LORD are trustworthy, making wise the simple. ${ }^{8}$ The precepts of the LORD are right, giving joy to the heart. The commands of the

\footnotetext{
46 BDB, 435-36.

47 Kidner, Proverbs, 103.

48 Franz Delitzsch, Biblical Commentary on the Proverbs of Solomon, trans. Matthew

G. Easton, BCOT, 2 vols. (Grand Rapids: Eerdmans, 1950), 1:279.
} 
LORD are radiant, giving light to the eyes. ${ }^{9}$ The fear of the LORD is pure, enduring forever. The ordinances of the LORD are sure and altogether righteous. ${ }^{10}$ They are more precious than gold, than much pure gold; they are sweeter than honey, than honey from the comb. ${ }^{11}$ By them is your servant warned; in keeping them there is great reward (NIV).

Since the direction provided by Yahweh's tôrāh is the way of health, knowledge and wellbeing, Prov 28:4-5 restate another basic message of Yahweh's tôrāh:

Those who forsake the law praise the wicked, but those who keep the law resist them. Evil men do not understand justice, but those who seek the LORD understand it fully.

Forsaking Yahweh's tôrāh implies forsaking direction and life. A society and people that forsake Yahweh's tôrāh lose wisdom and thereby all direction. Solomon pursues the result. Love of God and obedience to him are inseparable. The one is the necessary outcome of the other, so that "Yahweh's seekers" (28:5) and "tôrāh's keepers" (28:4) are the same person. The lives of such people are a more powerful reproof to the godless and wicked than any words which they can utter. Thus all neglect of Yahweh's tôrāh is a commendation of sin. Here every man is on one side or the other, and all who are not contending with the wicked by keeping Yahweh's tôrāh are countenancing their evil courses by their own forsaking of Yahweh's tôrāh. The one keeping Yahweh's tôrāh (28:7) takes delight in Yahweh, lives in fellowship with the truth and thus a companion of those who fear Yahweh and keep his precepts and he is therefore fortunate (29:18). The regulatory and basic assumption of life which enhances a man and improves his days with wisdom is ירֵֵַת יהוָה "the fear of Yahweh," which is intimately linked with Yahweh's tôrāh. The significance of tôrāh to life is dynamically set forth in another proverb: "He who turns away his ear from listening to the law (tôrāh), even his prayer is an abomination" (Prov 28:9). Thus, the one who rejects Yahweh's tôrāh denies himself/herself any relationship of fellowship with Yahweh. Consequently, such a person's prayer will be distasteful to Yahweh. This is a moral offence; for to pray to Yahweh whose tôrāh or instruction one rejects is to multiply ones transgressions. ${ }^{49}$

One of the most steadfast desires of men is to walk with knowledge of what the future holds. The means provided whereby man can know the future is the tôrāh-word of God. In terms of this, the psalmist announced, in his wonderful meditation on tôrāh in Ps 119: "Your law (tôrāh) is a lamp to my feet, and a light to my paths. I have sworn and determined to keep the judgments of thy righteousness" (Ps 119:105-106). This basic concept of tôrāh as man's guide appears again and again in scripture, perhaps first of all, by Solomon: "For the

49 Rushdoony, Institutes, 692. 
commandment of the law (tôrāh) is a lamp and a light; a way of life; reproof also and correction" (Prov 6:23). The one, who walks by faith in compliance to Yahweh's tôrāh, walks to a significant extent by sight. In this regards, to walk without Yahweh's tôrāh is to walk in darkness. ${ }^{50}$

\section{D תוֹרֵה MALACHI'S USE IN HIS DIALOGUE}

In an attempt to communicate Yahweh's massage to a band of disillusioned and contemptible exiles from Babylon, Malachi ${ }^{51}$ employs a fairly unique literary format which many scholars have given different labels. ${ }^{52}$ The discussion, dialogue, or disputation are classified into 6 oracle units ${ }^{53}$ of varying structures, ${ }^{54}$

50 Rushdoony, Institutes, 692.

51 It is not within the scope of this article to discuss issues of authorship, date, context of the book of Malachi. Several publications of Malachi's scholars including this writer have highlighted these issues. See Eileen M. Schuller, "The Book of Malachi," NIB 6:847; Elie Assis, "Structure and Meaning in the Book of Malachi," in Prophecy and the Prophets in Ancient Israel: Proceedings of the Oxford Old Testament Seminar, ed. John Day, LHBOTS 531 (New York: T \& T Clark, 2010), 354-369; Blessing Onoriode Boloje and Alphonso Groenewald, "Literary Analysis of Covenant Themes in the Book of Malachi," OTE 28/2 (2015): 257-282, Doi: http://dx.doi.org/10.17159/2312$\underline{3621 / 2015 / \mathrm{v} 28 \mathrm{n} 2 \mathrm{a} 4 \text {. }}$

52 The different labels given to the book as observed by scholars includes among others: "confrontational dialogue," John D. Hendrix, "You Say': Confrontation Dialogue in Malachi," RevExp 84 (1987): (465); “covenant lawsuit,” Julia M. O’Brien, Priest and Levite in Malachi, SBLDS 121 (Atlanta: Scholars, 1990), 63; "teaching method," Mark J. Boda, "Haggai: Master Rhetorician,” TynBul 51/2 (2000): 299-300; "question and answer technique," Eugene H. Merrill, Haggai, Zechariah and Malachi: An Exegetical Commentary (Chicago: Moody Press, 1994), 380; and "prophetic disputation and polemical argument," Clendenen, "Malachi," 218.

53 See Andrew E. Hill, Malachi: A New Translation with Introduction and Commentary, AB (New York: Doubleday, 1998), 26.

54 David J. Clark and Howard A. Hatton, A Handbook on Haggai, Zechariah and Malachi (New York: United Bible Societies, 2002), 370; Gordon P. Hugenberger, Marriage as a Covenant: Biblical Law and Ethics Governing Marriage Developed from the Perspective of Malachi, VTSup 52 (Leiden: Brill, 1994), 24-25; David A. Dorsey, The Literary Structure of the Old Testament: A Commentary on Genesis to Malachi (Grand Rapids: Baker Book House, 1999), 323. 
a superscription ${ }^{55}$ one or two postscripts or epilogues ${ }^{56}$ and diversity of themes. ${ }^{57}$ Malachi consists of judgement oracles within which are disputations, perhaps reminiscent of the courtroom. The disputation may include a claim, a hypothetical audience response, and an answer that leaves the accused with no further recourse. The author uses and adapts a complex variety of OT texts, drawn especially from the Genesis narratives, the covenant code of Exod 20:2223:33, the Holiness Code of Lev 17-26, Deuteronomy, and other poetic materials in the Deuteronomistic History and in the prophets and Psalms. ${ }^{58}$ A brief summary of materials used is provided:

Judgements against Edom (e.g. Obadiah; Jer. 49:7-22; Amos 9:12 etc.) are found in a salvation oracle for Israel (Mal. 1:2-5). Levitical laws on burnt offerings (Lev. 1; 6:9-12; 22:17-19) provide foundation for Malachi 1:7-8 and sacrifices. The use of courses for breaking covenant (Mal. 2:2-3) occurs in Deuteronomy 28:15-68. For the one whose covenant is with God (Mal. 2:5-6), compare the Servant Songs of Isaiah 42:1-4; 49:1-4; 52:13-53:12. Malachi 2:14-16 reflects and

55 Hill, Malachi, 26; Clendenen, "Malachi," 227.

56 Malachi's epilogues (4:4 [MT 3:22]; 4:5-6 [MT 3:23-24]) have been a major concern of scholarly debate. Malachi's interpreters hold that these verses are Scribal or editorial inclusion to the book, with different functions. For a discussion regarding the debates on the epilogues see, Karel Van der Toorn, Scribal Culture and the Making of the Hebrew Bible (London: Harvard University Press, 2007), 253; Richard J. Coggins and Jin H. Han, Six Minor Prophets through the Century: Nahum, Habakkuk, Zephaniah, Haggai, Zechariah and Malachi (Malden, MA.: Wiley \& Sons/WileyBlackwell, 2011), 199-200; Elie Assis, "Moses, Elijah and the Messianic Hope: A New Reading of Malachi 3:22-24," ZAW 123/2 (2011): 208-209, Doi: https://doi.org/10.1515/zaw.2011.013; Russell Fuller, "The Sequence of Malachi 3:2224 in the Greek and Hebrew Textual Traditions: Implications for the Redactional History of the Minor Prophets," in Perspectives of the Formation of the Book of the Twelve, ed. Rainer Albertz, James D. Nogalski, and Jakob Wohrle (Berlin: Walter de Gruyter, 2012), 371-73; Fanie S. D. Snyman, "Malachi 4:4-6 (Heb 3:22-24) as a Point of Convergence in the Old Testament or Hebrew Bible: A Consideration of the Intra and Intertextual Relationships," HTS 68/1 (2012): 2; Art. \#1195, 6 pages; Doi: https://doi.org/10.4102/hts.v68i1.1195.

57 For discussions regarding themes in the book of Malachi, see Jason T. LeCureux, The Thematic Unity of the Book of the Twelve, HBM 41 (Sheffield: Sheffield Phoenix Press, 2012), 16; James D. Nogalski, "Recurring Themes in the Book of the Twelve: Creating Points of Contact for a Theological Reading," Int 61/2 (2007): 125; Rolf Rendtorff, "How to Read the Book of the Twelve as a Theological Unity," in Reading and Hearing the Book of the Twelve, ed. James D. Nogalski and Marvin A. Sweeney, SBLSymS 15 (Atlanta: Society of Biblical Literature, 2000), 75-87; Terence Collins, The Mantle of Elijah: The Redaction Criticism of the Prophetic Books, BibSem 20 (Sheffield: Sheffield Academic Press, 1993), 65; Paul L. Redditt, "Themes in HaggaiZechariah-Malachi," Int 61 (2007): 184-197.

58 Hess, Old Testament, 708. 
develops the monogamous marriage commitment of Genesis 2:2324... God's eternal existence ensures his faithfulness (Mal. 3:6; Exod. 6:5; Lev. 26:40-42; Ps.111:9; Jer. 31:20). In terms of specific concerns of intermarriage, divorce, and maintaining the temple cult, the reader finds echoes in Chronicles, Ezra, and Nehemiah. ${ }^{59}$

In Malachi's dialogue, תiֹ appears first in his criticism of contemporary ministry colleagues (Mal 2:6-9), who unlike Levi failed to honour Yahweh and stood in respect of his name. He describes Levi as one who rendered true and precise interpretation of Yahweh's tôrāh and in whose mouth was genuine instruction (tôrāh) and on his lips no corruption, perversity, iniquity, wickedness or unrighteousness could be found. Because compliance to Yahweh's tôrāh marked out Israel's fidelity to their covenant relationship with Yahweh, Israel's life thus hinged on faithful discharge of priestly responsibility. ${ }^{60}$ Priestly instructional duties were closely linked with emphasis on the essential contents of Yahweh's written instruction to Israel through Moses (Yahweh's tôrāh) and collective access to this authoritative instructions or text is reflected in Deuteronomy. ${ }^{61}$ By neglecting their ministerial and instructional responsibilities; be it by priestly instruction, educational guideline or prophetic oracle, Malachi's colleagues rather than turning many away from sin, their tôrāh (instruction) made many stumble and do sinful things. ${ }^{62}$ Their service of disloyalty morally corrupted the revered covenant with Levi and as such they forfeited their privileges in it. ${ }^{63}$

After a series of confrontational dialogues, Malachi returns to an exhortation to tôrāh compliance in his epilogue (Mal 4:4 [MT 3:22]). Malachi's imperative exhortation to remember (זְְָ) Yahweh's tôrāh invites Israel to live out or embodies their intellectual understanding of Yahweh's dealing with them in history (cf. Exod 13:3; Deut 5:15; Ps 77:11), faithfully aligning and conforming their will to the instructions (tôrāh) of Yahweh through his servant Moses. Such intelligent acknowledgement and unconditional commitment and conformity will stimulate Israel to fear Yahweh and reverence his name. The

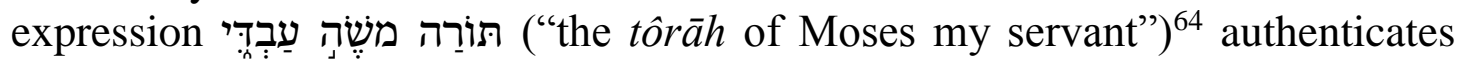

59 Hess, Old Testament, 708.

60 Clendenen, "Malachi," 312; Lena-Sofia Tiemeyer, Priestly Rites and Prophetic Rage: Post-exilic Prophetic Critique of the Priesthood, FAT 2/19 (Tubingen: Mohr Siebeck, 2006), 131.

61 Martha Himmelfarb, Between Temple and Torah: Essays on Priests, Scribes, and Visionaries in the Second Temple Period and Beyond, TSAJ 151 (Tübingen: Mohr Siebeck, 2013), 95-96.

62 O'Brien, Priest and Levite 35-36.

63 James N. Pohlig, An Exegetical Summary of Malachi (Dallas, TX.: Summer Institute of Linguistics Inc., 1998), 85.

64 Diversity of opinions exists regarding the basic idea of tôrāt mosheh. James Nogalski holds it is a reference to Malachi's book. See James D. Nogalski, “The Day(s) 
Malachi's understanding of Israel's tradition of Moses ${ }^{65}$ as the mediator of Yahweh's tôrāh and whose service is an epitome of the standard most delightful to Yahweh. ${ }^{66}$ Moses' tôrāh (תוֹרֵת משֶׁה ) summarizes Israel's life and mission under God; it implies life or death, blessing or cursing for Israel (cf. Deut 30:1520). ${ }^{67}$

In the Sinai Covenant Theology, Yahweh's tôrāh functions as Israel's response to Yahweh's saving actions. Thus Israel is called in light of their present condition of sin, rebellion or disobedience to remember and return to Yahweh which will in turn quicken Yahweh to remember and return to them with forgiveness, fruitfulness, vindication and prosperity which they forfeited on account of forsaking Yahweh's tôrāh. ${ }^{68}$ Regarding the restorative impact of the Malachi's exhortation to remember Yahweh's tôrāh Marvin A. Sweeney notes:

Malachi's rhetorical goal appears not only to be to exhort the priests and people to observe YHWH's Torah but to convince them to do so as a united community in which the strife that has divided its members over proper understanding of YHWH and observance of YHWH's Torah is overcome. ${ }^{69}$

\section{E SYNTHESIS AND CONCLUSION}

This article's focus was to examine the connection between Malachi's use of תis in his dialogue and the wisdom tradition of Proverbs with the basic proposition that wisdom in the book of Proverbs is tôrāh-oriented and that Malachi's use of tôrāh serve to present and elevate tôrāh as Israel's Wisdom

of YHWH in the Book of the Twelve," in Thematic Threads in the Book of the Twelve, ed. Paul L. Redditt and Aaron Schart, BZAW 325 (Berlin: De Gruyter, 2003), 195-196. Michael H. Floyd considers the reference to be identical with the book of Deuteronomy. Michael H. Floyd, Minor Prophets, Part 2 (Forms of the Old Testament Literature vol. 22; Grand Rapids: Eerdmans / Baker Books, 2000), 2:625. Others see it as a reference to the whole Pentateuch. See, Paul L. Redditt, Haggai, Zechariah and Malachi, NCB (Grand Rapids: Eerdmans, 1995), 185; Hill, Malachi, 366.

65 The covenant law or stipulations handed over to Israel through Moses that regulates her relationship with Yahweh are indicated by the ideas of keeping Yahweh's "statutes and ordinances," or "decrees and regulations" (Deut 6:1, 3; cf. Deut 4:23; 5:1, 22; 6:34; 7:11-12). See Andrew E. Hill, Haggai, Zechariah and Malachi: An Introduction and Commentary, TOTC 28 (Downers Grove, IL: Inter-Varsity Press, 2012), 363; John Kessler, Old Testament Theology: Divine Call and Human Response (Waco, TX.: Baylor University Press, 2013), 119.

66 Beth Glazier-McDonald, Malachi: The Divine Messenger, SBLDS 98 (Atlanta: Scholars, 1987), 249.

67 Hill, Haggai, 367.

68 Kessler, Old Testament Theology, 252-253.

69 Marvin A. Sweeney, The Twelve Prophets (Collegeville, PA.: Liturgical Press, 2000), 750 . 
Tradition/teaching. In this article, the HB/OT understanding of wisdom is briefly examined as well as the ideals of keeping, forsaking and remembering Yahweh's tôrāh in Proverbs and Malachi.

Although significant OT theological themes such as covenant history, tôrāh, and prophetic proclamation are not frequently mentioned in Wisdom literature, thus "wisdom sometimes appears to be the stepchild of the canonical family... Simply put the wisdom literature does not seem to fit in with the rest of the Old Testament." 70 The observation regarding the silence of redemptive and covenant events in the history of Israel by the sages is also noted by David Penchansky in his introduction to the Wisdom literature when he said, "The sages did not regard the Israelite covenants to be important ... because they were concerned about other things." ${ }^{71}$ Whilst wisdom is portrayed as an autonomous tradition in connection with the Law and the Prophetic books, Richard L. Schultz demonstrates that the connection between wisdom corpus and other OT literature can be consciously bridged through intertextual relationship and integration. ${ }^{72}$ The correspondence between tôrāh and wisdom is observed in Robert B. Y. Scott description of "the functions of prophet, priest, and sage, and of a common element in their teachings." Robert notes that although

Isaiah and Jeremiah scorn the wise men of their time, yet they themselves adopt some of the language, forms, and ideas of the wisdom teachers. The priests (again, if Deuteronomy represents their teaching) are concerned with the wisdom embodied in the traditional torah; the keeping of the statutes and ordinances of Yahweh would give Israel a reputation among the nations as "a wise and understanding people." 73

Canonical wisdom teaching as found in Proverbs calls for right behaviour with focus on the advantages and disadvantages of doing the right thing namely; living according to Yahweh's tôrāh. ${ }^{74}$ Proverbs defines wisdom as "keeping and following Yahweh's tôrāh," for to obtain wisdom and understanding is to follow tôrāh:

See, I have taught you statutes and judgments just as the LORD my God commanded me, that you should do thus in the land where you

70 Duane E. Garrett, Proverbs, Ecclesiastes, Song of Songs, NAC (Nashville: B\&H, 1993), 21.

71 David Penchansky, Understanding Wisdom Literature: Conflict and Dissonance in the Hebrew Text (Grand Rapids: Eerdmans, 2012), 82.

72 Richard L. Schultz, "Unity or Diversity in Wisdom Theology? A Canonical and Covenantal Perspective," TynBul 48/2 (1997): 271-306.

73 Robert B. Y. Scott, "Priesthood, Prophecy, Wisdom, and the Knowledge of God," JBL 80/1 (1961): 3-4, Doi: https://doi.org/10.2307/3264562.

74 Christopher J. H. Wright, Walking in the Ways of the Lord: The Ethical Authority of the Old Testament (Leicester: Apollos, 1995), 120-22. 
are entering to possess it. So keep and do them, for that is your wisdom and your understanding in the sight of the peoples who will hear all these statutes and say, "Surely this great nation is a wise and understanding people." ... Or what great nation is there that has statutes and judgments as righteous as this whole law which I am setting before you today? (Deut 4:5-6, 8).

Solomon links three things, namely: the fear of Yahweh and his instruction, direction, or tôrāh; the tôrāh as applied by father and mother to son; the consequence of obedience to this direction is an ornament or crown of life to the son:

The fear of the LORD is the beginning of knowledge; Fools despise wisdom and instruction. Hear, my son, your father's instruction, and do not forsake your mother's teaching (tôrāh). Indeed, they are a graceful wreath to your head, and ornaments about your neck (Prov $1: 7-9)$.

Yahweh's tôrāh makes provision for a healthy and viable society. In Proverbs however, forsaking Yahweh's tôrāh (Prov 28:4) led the influential and well-off to easily oppress the weak and poor. Their leadership only benefited themselves and not those they rule (Prov 28:3; cf. 29:2,4). They give no attention to the requirement of justice since they are bereft of any knowledge of it (28:5; 29:7) and accumulated wealth and riches by inflated and excessive interest rate (28:8). Forsaking Yahweh's tôrāh resulted in lawlessness and this ultimately causes disruption in families and societies $(28: 12 ; 29: 2)$.

Malachi's corresponding exhortation to all Israel on the urgency of remembering Yahweh's tôrāh situates tôrāh as Israel's wisdom teaching. His exhortation is noticeably a call to daily living and practical experience that is grounded not in societal expectations, human wisdom and desires but on painstaking, thorough and contemplative application of Yahweh's tôrāh. This tôrāh-wisdom exhortation implies that, "It is only through this divine lighthouse that Yahweh's people can be guided to avoid destruction on 'that great and dreadful day." "75 Remembering Yahweh's tôrāh will cause Israel to fear Yahweh (which is wisdom), rightly practise the cult, stimulate covenant fidelity, give attention to the urgent demands of justice and brings about restoration of fortunes. Whatever the future holds or looks like, whether impressive or not; a deliberate, conscious, sincere and wholehearted commitment to Yahweh's tôrāh

75 Blessing O. Boloje and Alphonso Groenewald, "Malachi's Concept of a TorahCompliant Community (M1 3:22 [MT]) and its Associated Implications," HTS 71/3 (2015): 6, Art. \#2990, 9 pages, Doi: https://doi.org/10.4102/hts.v71i3.2990. 
will be the only guarantee of the needed wisdom for a fruitful, healthy, wholesome individual and community well-being. ${ }^{76}$

The exhortation to remember Yahweh's tôrāh is a call to the entire Judahite community for an urgent appropriation and application of Yahweh's tôrāh to life and current situation. This will guarantee them a reputation in the anticipated return of the Messenger of the covenant, who will prepare Yahweh's way and bring fire of purification on the priests so that Yahweh's people will bring righteous offerings. Yahweh will put on trial and testify against all sorcerers, adulterers, perjured, and those who defraud and oppress the vulnerable (2:17-3:5). Yahweh's action on the day of his visitation will inspire the hope of the righteous (3:17-18) and reduce the wicked to disgrace and utter destruction. The Judahites' response to the exhortation to remember Yahweh's tôrāh will cause them to make the most appropriate decision. This will be expressed only

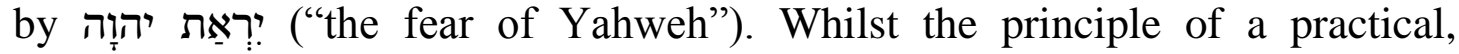
intelligent and wise life may be discernible in much of the Wisdom literature; however, behind wisdom teachings of the OT lies the certainty that Yahweh's tôrāh enthusiastically and potentially invigorates right moral decisions and societal order.

\section{BIBLIOGRAPHY}

Albertz, Rainer, From the Exile to the Maccabees. Vol. 2 of A History of Israelite Religion in the Old Testament Period. Louisville: Westminster John Knox Press, 1994.

Arnold, Bill T. and Bryan E. Beyer, Readings from the Ancient Near East: Primary Sources for Old Testament Studies. Grand Rapids: Baker, 2002.

Assis, Elie, "Structure and Meaning in the Book of Malachi." Pages 354-369 in Prophecy and the Prophets in Ancient Israel: Proceedings of the Oxford Old Testament Seminar. Edited by John Day. LHBOTS 31. New York: T \& T Clark 2010.

."Moses, Elijah and the Messianic Hope: A New Reading of Malachi 3:2224." ZAW 123/2 (2011): 207-220. https://doi.org/10.1515/zaw.2011.013.

Ben-Dov, Jonathan, "Some Precedents for the Religion of the Book: Josiah's Book and Ancient Revelatory Literature." Pages 43-62 in Constructs of Prophecy in the Former and Latter Prophets and Other Texts. Edited by Lester L. Grabbe and Martti Nissinen, ANEM 4. Atlanta, GA.: Society of Biblical Literature, 2011.

Boda, Mark J., "Haggai: Master Rhetorician.” TynBul 51/2 (2000): 295-304.

Boloje, Blessing Onoriode and Alphonso Groenewald, "Malachi's Concept of a Torah-Compliant Community (Ml 3:22 [MT]) and its Associated Implications." HTS 71/3 (2015). Art. \#2990. 9 pages. https://doi.org/10.4102/hts.v71i3.2990.

76 Louis Stulman and Hyun C. P. Kim, You are My People: An Introduction to the Prophetic Literature (Nashville: Abingdon Press, 2010), 243. 
Boloje, Blessing Onoriode and Groenewald, Alphonso, "Literary Analysis of Covenant Themes in the Book of Malachi." OTE 28/2 (2015): 257-282. https://doi.org/10.17159/2312-3621/2015/v28n2a4.

Bricker, Daniel P, “The Doctrine of the 'Two Ways' in Proverbs.” JETS 38/4 (1995): 500-17.

Brown, Francis, Samuel R. Driver, and Charles A. Briggs, A Hebrew and English Lexicon of the Old Testament. Peabody: Hendrickson Publishers, 1997.

Clark, David J. and Howard A. Hatton, A Handbook on Haggai, Zechariah and Malachi. New York: United Bible Societies, 2002.

Clements, Roland E, Wisdom Theology. Carlisle: Paternoster, 1992. . "The Meaning of Torah in Isaiah 1-39." Pages 59-72 in Reading the Law: Studies in Honour of Gordon J. Wenham. Edited by J. Gordon McConville and Karen Miller, LHBOTS 461. New York: T \& T Clark International, 2007.

Clendenen, E. Ray. "Malachi." Pages 203-464 in Haggai, Malachi. Edited by Richard A. Taylor and E. Ray Clendenen, NAC 21A. Nashville, TN.: Broadman and Holman Publishers, 2004.

Coggins, Richard J. and Jin H. Han, Six Minor Prophets through the Century: Nahum, Habakkuk, Zephaniah, Haggai, Zechariah and Malachi. Malden, MA.: Wiley \& Sons/Wiley-Blackwell, 2011. https://doi.org/10.1002/978144434 2826

Collins, Terence, The Mantle of Elijah: The Redaction Criticism of the Prophetic Books. BibSem 20; Sheffield: Sheffield Academic Press, 1993.

Crenshaw, James L, Old Testament Wisdom: An Introduction. 3rd ed. Louisville: Westminster John Know, 2010.

Delitzsch, Franz, Biblical Commentary on the Proverbs of Solomon. Translated by Matthew G. Easton. BCOT. 2 vols. Grand Rapids: Eerdmans, 1950.

Dell, Katharine J, "Deciding the Boundaries of Wisdom: Applying the Concept of Family Resemblance." Pages 145-160 in Was there a Wisdom Tradition? New Prospects in Israelite Wisdom Studies. Edited by Mark R. Sneed. AIL 23. Atlanta: SBL Press, 2015. https://doi.org/10.2307/j.ctt173zmjp.10

Dorsey, David A, The Literary Structure of the Old Testament: A Commentary on Genesis to Malachi. Grand Rapids: Baker Book House, 1999.

Drane, John, Introducing the Old Testament. 2nd rev. ed. Minneapolis: Fortress Press, 2001.

E-Agbikimi, Nathaniel A., Wisdom: A Prerequisite for Long Life in a World Full of Hazards. Effurun: Journey Designs, 2011.

Floyd, Michael H, Minor Prophets, Part 2. The Forms of the Old Testament Literature vol. 22. Grand Rapids: Eerdmans / Baker Books, 2000.

Fox, Michael V, “Three Theses on Wisdom.” Pages 69-86 in Was there a Wisdom Tradition? New Prospects in Israelite Wisdom Studies. Edited by Mark R. Sneed. AIL 23. Atlanta: SBL Press, 2015. https://doi.org/10.2307/j.ctt173zmjp.7

Fuller, Russell, "The Sequence of Malachi 3:22-24 in the Greek and Hebrew Textual Traditions: Implications for the Redactional History of the Minor Prophets." Pages 371-379 in Perspectives of the Formation of the Book of the Twelve. Edited by Rainer Albertz, James D. Nogalski, and Jakob Wohrle. Berlin: Walter de Gruyter, 2012. https://doi.org/10.1515/9783110283761.371

Garrett, Duane E, Proverbs, Ecclesiastes, Song of Songs. NAC. Nashville: B\&H, 1993. 
Glazier-McDonald, Beth, Malachi: The Divine Messenger. SBLDS 98. Atlanta: Scholars, 1987.

Groenewald, Alphonso,. "The Significance of הרות (Isa 2:3) within Isaiah 2:1-5: The Relationship of the First Overture (1:1-2:5) to the Book's Conclusion (Isa 6566)." OTE 26/3 (2013): 695-717. . "The Role and Function of Sedaqa and Torah in the Introduction to the Book of Isaiah (1.1-2.5)." Pages 71-85 in Sedaqa and Torah in Postexilic Discourse. Edited by Suzanne Gillmayr-Bucher and Maria Häusl, LHBOTS 640. New York: Bloomsbury T \& T Clark, 2017.

Hendrix, John D., “'You Say': Confrontation Dialogue in Malachi.” RevExp 84 (1987): 465-77. https://doi.org/10.1177/003463738708400310

Hess, Richard S., The Old Testament: A Historical, Theological and Critical Introduction. Grand Rapids: Baker Academic, 2016.

Hill, Andrew E., Malachi: A New Translation with Introduction and Commentary. AB. New York: Doubleday, 1998.

. Haggai, Zechariah and Malachi: An Introduction and Commentary. TOTC 28. Downers Grove: Inter-Varsity Press, 2012.

Himmelfarb, Martha, Between Temple and Torah: Essays on Priests, Scribes, and Visionaries in the Second Temple Period and Beyond. TSAJ 151. Tübingen: Mohr Siebeck, 2013.

Hugenberger, Gordon P, Marriage as a Covenant: Biblical Law and Ethics Governing Marriage Developed from the Perspective of Malachi. VTSup 52. Leinen: Brill, 1994.

Kessler, John, Old Testament Theology: Divine Call and Human Response. Waco, TX: Baylor University Press, 2013.

Kidner, Derek, Proverbs: An Introduction and Commentary. Downers Grove: InterVarsity Press, 1975. . The Wisdom of Proverbs, Job and Ecclesiastes. Downers Grove: InterVarsity Press, 1985.

Kristilere, Israel, Seven Pillars of Wisdom. Lagos: Oasis of Faith Ventures, 2014. Kynes, Will, "The Modern Scholarly Wisdom Tradition and the Threat of PanSapientialism: A Case Report." Pages 11-38 in Was there a Wisdom Tradition? New Prospects in Israelite Wisdom Studies. Edited by Mark R. Sneed. AIL 23. Atlanta: SBL Press, 2015. https://doi.org/10.2307/j.ctt173zmjp.5

LeCureux, Jason T., The Thematic Unity of the Book of the Twelve. HBM 41. Sheffield: Sheffield Phoenix Press, 2012.

Lindars, Barnabas, "Torah in Deuteronomy." Pages 117-173 in Words and Meanings: Essays Presented to David Winton Thomas. Edited by Peter R. Ackroyd and Barnabas Lindars. Cambridge: Cambridge University Press, 1968.

Longman III, Tremper, How to Read Proverbs. Downers Grove: Inter-Varsity Press, 2002.

Merrill, Eugene H., Haggai, Zechariah and Malachi: An Exegetical Commentary. Chicago: Moody Press, 1994.

Miller, Douglas, "Wisdom in the Canon: Discerning the Early Intuition." Pages 87114 in Was there a Wisdom Tradition? New Prospects in Israelite Wisdom Studies. Edited by Mark R. Sneed. AIL 23. Atlanta: SBL Press, 2015. https:// doi.org/10.2307/j.ctt173zmjp.8 
Murphy, Roland, "Wisdom." Pages 920-931 in vol. 6 of The Anchor Bible Dictionary. Edited by David N. Freedman. 6 Volumes. Garden City, NY: Doubleday, 1992.

Nogalski, James D., "The Day(s) of YHWH in the Book of the Twelve." Pages 192213 in Thematic Threads in the Book of the Twelve. Edited by Paul L. Redditt and Aaron Schart. BZAW 325. Berlin: De Gruyter, 2003. https://doi.org/ $\underline{10.1515 / 9783110892512.192}$

. "Recurring Themes in the Book of the Twelve: Creating Points of Contact for a Theological Reading." Int 61/2 (2007): 125-36. https://doi.org/ $\underline{10.1177 / 002096430706100202}$

O'Brien, Julia M., Priest and Levite in Malachi. SBLDS 121. Atlanta: Scholars, 1990.

Penchansky, David,. Understanding Wisdom Literature: Conflict and Dissonance in the Hebrew Text. Grand Rapids: Eerdmans, 2012.

Pitkanen, Pekka, "The Use of Priestly Legal Tradition in Joshua and the Composition of the Pentateuch and Joshua." OTE 29/2 (2016): 318-35. https://doi.org/ $10.17159 / 2312-3621 / 2016 / \mathrm{v} 29 \mathrm{n} 2 \mathrm{a} 6$

Pohlig, James N, An Exegetical Summary of Malachi. Dallas, TX.: Summer Institute of Linguistics Inc., 1998.

Redditt, Paul L, “Themes in Haggai-Zechariah-Malachi.” Int 61 (2007): 184-97. https://doi.org/10.1177/002096430706100206

. Haggai, Zechariah and Malachi. NCB. Grand Rapids: Eerdmans, 1995.

Rendtorff, Rolf, "How to Read the Book of the Twelve as a Theological Unity." Pages 75-87 in Reading and Hearing the Book of the Twelve. Edited by James D. Nogalski and Marvin A. Sweeney. SBLSymS 15. Atlanta: Society of Biblical Literature, 2000.

Richards, Lawrence O, Bible Reader's Companion. Eastbourne, England: Cook Communications Ministries, 2004.

Ross, Allen P. "Proverbs." Pages 881-1134 in vol. 5 of The Expositor's Bible Commentary. Edited by Frank E. Gaebelein. Grand Rapids: Zondervan, 1991.

Routledge, Robin, Old Testament Theology: A Thematic Approach. England: InterVarsity Press, 2008.

Rushdoony, Rousas John, The Institutes of Biblical Law. Nutley, NJ: The Craig Press, 1973.

Schuller, Eileen M, "The Book of Malachi." Pages 843-77 in vol. 6 of The New Interpreter's Bible. Edited by Leander E. Keck. Nashville: Abingdon Press, 1996.

Schultz, Richard L., "Unity or Diversity in Wisdom Theology? A Canonical and Covenantal Perspective." TynBul 48/2 (1997): 271-306.

Scott, Robert B.Y., "Priesthood, Prophecy, Wisdom, and the Knowledge of God." JBL 80/1 (1961): 1-15. https://doi.org/10.2307/3264562.

Sneed, Mark R., "'Grasping after the Wind': The Elusive Attempt to Define and Delimit Wisdom." Pages 39-68 in Was there a Wisdom Tradition? New Prospects in Israelite Wisdom Studies. Edited by Mark R. Sneed. AIL 23. Atlanta: SBL Press, 2015. https://doi.org/10.2307/j.ctt173zmjp.6 . ed. Was there a Wisdom Tradition? New Prospects in Israelite Wisdom Studies. AIL 23. Atlanta: SBL Press, 2015.

Snyman, Fanie S.D., "Malachi 4:4-6 (Heb 3:22-24) as a Point of Convergence in the Old Testament or Hebrew Bible: A Consideration of the Intra and Intertextual 
Relationships.” HTS 68/1 (2012). Art.\#1195. 6 pages. Doi: $10.4102 /$ ids.v50i1 .2091

Steinmann, Andrew E., "Proverbs 1-9 as a Solomonic Composition." JETS 43/4 (2000): 660-74.

Stulman, Louis and Hyun C. P. Kim, You are My People: An Introduction to the Prophetic Literature. Nashville: Abingdon Press, 2010.

Sweeney, Marvin A., The Twelve Prophets. Collegeville, PA.: Liturgical Press, 2000.

Tiemeyer, Lena-Sofia, Priestly Rites and Prophetic Rage: Post-exilic Prophetic Critique of the Priesthood. FAT 2/19. Tübingen: Mohr Siebeck, 2006.

Tov, Emanuel, Textual Criticism of the Hebrew Bible. 3rd ed. Minneapolis: Fortress Press, 2012.

Van der Toorn, Karel, Scribal Culture and the Making of the Hebrew Bible. London: Harvard University Press, 2007.

Waltke, Bruce K., The Book of Proverbs, Chapters 1-15. NICOT. Grand Rapids: Eerdmans, 2004.

Waltke, Bruce K and Diewert, David, "Wisdom Literature." Pages 295-328 in The Face of Old Testament Studies: A Survey of Contemporary Approaches. Edited by David W. Baker and Bill T. Arnold. Grand Rapids: Baker, 1999.

Wright, Christopher J.H., Walking in the Ways of the Lord: The Ethical Authority of the Old Testament. Leicester: Apollos, 1995.

Blessing Onoriode Boloje is a lecturer at the Baptist Theological Seminary, EkuNigeria and Research Associate, Department of Old Testament Studies, Faculty of Theology, University of Pretoria, 0002, Pretoria. Email: pstbobson@yahoo.co.uk. ORCID ID: https://orcid.org/0000-0002-7480-3805 